\title{
E-LEARNING STUDENT SATISFACTION IN HIGHER EDUCATION BLENDED PROGRAMS: COMPARING ONLINE AND OFFLINE CLASS LEARNING EXPERIENCE
}

\author{
Reikman Aritonang \\ Haruka Evolusi Digital Utama, Ruko Sentra Arteri Mas No.10L, Jl. Sultan Iskandar \\ Muda No.10, Kebayoran Lama, Jakarta 12240, Jakarta, Indonesia \\ reikman.aritonang@harukaedu.com
}

\section{Gerald Ariff}

Bina Nusantara University, Joseph Wibowo Center Campus

JI. Hang Lekir I No. 6, Senayan, Jakarta 10270 Indonesia, Indonesia

gerald@harukaedu.com

\begin{abstract}
:
Student satisfaction is an important component influencing student learning outcomes and recruitment achievement, yet previous researches show this issue tends to be overlooked in developing study program quality in higher education institutions. Student satisfaction becomes more important in building e-learning programs as students are expected to be more independent in doing their learning responsibilities. This research is aimed to examine student satisfaction in blended programs from different universities in order to find out how students perceived their learning experiences in e-learning programs. Assessing student satisfaction in blended program also provides an opportunity to compare student satisfaction in online and offline classes as Indonesia regulation requiring higher education institutions who offer such programs maintaining a regulated portion between online and offline courses. Research data is gathered from surveys of learning outcome assessments in both online and offline courses in different blended programs in different universities. In order to achieve the research objectives, statistical methods are employed to analyze factors affecting student satisfaction and comparing student satisfaction in online and offline courses. Data analysis is expected to show that different factors may affect student satisfaction in online and offline courses. Such expectation is motivated from the hypothesis that students may gain different learning experiences in different learning approaches. However, student satisfaction in online courses are expected to relatively equal with offline courses as the development of e-learning method is designed to reach the same learning quality as offline classes.
\end{abstract}

Key words: e-learning, student satisfaction, blended program, higher education

\section{ABOUT THE AUTHORS}

Reikman Aritonang: Partnership \& Program Management, PT. Haruka Edukasi Digital Utama, Jakarta, DKI Jakarta, Indonesia

Gerald Ariff: Lecturer, Bina Nusantara University, Jakarta, DKI Jakarta, Indonesia 


\section{INTRODUCTION}

Researches show that student satisfaction plays an important role in developing higher education programs and influence the learning outcome (see for examples Ammigan and Jones (2018), Weerasinghe and Fernando (2017), Goh et al (2017), Adnan et al (2016). Gortan and Jereb's study (2007) argue that ignoring student satisfaction factor in developing higher education study programs may cause high student dropout rate. They found that academic courses with high level of student satisfaction tend to have high retention rate, as well as low student academic performance. Given the importance of student satisfaction, however, this issue is still apart in in developing e-learning programs. Moreover, researchers tend to measure student satisfaction in face-to-face program and e-learning program using the same approaches, when in fact those learning programs have different methods in nature.

Weerasinghe and Fernando (2017) recognize that student satisfaction issue is complex due to such issue is related to multi-dimentional activities and variables throughout the learning process. For example, Hanssen and Solvoll (2015) extended student satisfaction assessment to include physical facilities. Their study found that the quality of social areas, auditoriums and libraries strongly influence student satisfaction, but computer access on campus does not influence student satisfaction. Daniel (2017) measured satisfaction level of students in relation to the overall service of university using SERVQUAL technique. By applying this approach, the study assume that the dimensions of SERVQUAL throughout university services are weighted equally. Strong et al (2012) attempted to relate student satisfaction into learning environment and social presence in order to measure collaboration among students. Zaheer at al (2015) employed a wider range of variables to measure student satisfaction level. Adnan et al (2016) elaborate the effect of demographic characteristics in measuring business school student satisfaction to argue that the factor contributes to student satisfaction. Farahmandian et al (2013) include tuition fee and financial assistant to measure student satisfaction.

Student satisfaction issue is even more sensitive in distance learning program where students interact more with virtual learning process. Gortan and Jereb (2007) argued that e-learning programs with higher student satisfaction have higher retention rate and high student academic performance. Online courses should be routinely assessed in order to potentially improve online course delivery (Strong et al, 2012)

\section{Previous researches tend to ignore}

The purpose of this study is to examine student satisfaction in blended program programs that offer both online and offline courses. In particular, this study focuses on assessing student experience in the classes in order to capture their satisfaction to the e-learning class quality. In addition, studying student satisfaction in blended programs can assess student satisfaction in both online classes and offline classes. It 
provides the opportunity to compare the student satisfaction in online class into student satisfaction in the face-to-face classes. Such opportunity is gained due to Indonesian e-learning related regulation offer 2 different types of e-learning program i.e. blended program and full e-learning program. Higher education institutions offering blended program have to maintain below $50 \%$ of online classes on the top of regular face-to-face classes. On the other hand, the full e-learning program is permitted to offer full online classes for the entire curriculum.

\section{Research Methodology}

This research employs quantitative research method for analyzing research data to answer the research objective. Research data is collected from class surveys in 10 blended programs that are run in 6 (six) different higher education institutions. Out of those Blended Programs, 6 (six) study programs are in undergraduate level and 4 (four) study programs are in post-graduate programs. The class surveys are conducted at the end of study period in each class in those 10 Blended Programs that include offline and online courses. Respondents for those surveys are students enrolled in the Blended Programs and completed their classes in each course. There are 1,932 students who completed the questionnaires at the end of their classes that include 1355 respondents in online classes and 577 respondents in offline classes.

Research data is processed using statistical methods where different statistical methods are employed during different stages of data analysis process. Initially, Durbin-Watson method is applied to test for autocorrelation in the data residuals to estimate the standard error of the predictors. The test is calculated with the formula:

$$
D W=\frac{\sum_{t=2}^{T}\left(e_{t}-e_{t-1}\right)^{2}}{\sum_{t=1}^{T} e_{t}^{2}}
$$

Collinearity diagnostics is applied to confirm problems with multicollinearity for identifying inter-correlation in the research data values. The condition indices are computed as the square roots of the eigenvalue to each successive eigenvalue. The procedure is plotted to detect non-linearity, influential observations and outliers. Consists of side-by-side quantile plots of the centered fit and the residuals. It shows how much variation in the data is explained by the fit and how much remains in the residuals. Student satisfaction in offline and online classes is computed for comparison using Analysis of Variance to test differences between means of those groups of variables. This technique is used for analyzing the variances of independent samples to arrive at the conclusion whether student satisfaction in online class is not different to student satisfaction in offline class. 
Research data is taken from student survey that students are required to filled-in after completing each course for both online and offline classes. Questionnaire is accessable in the Learning Management System (LMS) that student can access and submit virtually. Satisfaction perception is captured in the questionnaire through assessment whether students will recommend the study program with 1 to 10 scale. This current research follow HarukaEDU's high standard to measure student perception towards the quality of classes in the Blended Program. The student response to the measure is classified as follow 1-5 is unsatisfied, 6-8 is neutral and 9-10 is satisfied.

\section{Data analysis}

Data student satisfactory is presented in tables to categorize their experience perceive the distribution across program level. Table 1 shows that overall 38\% students are satisfied to their learning experience in online classes. The remaining $46 \%$ students are neutral and $17 \%$ students are dissatisfied to their learning experience. However, there are more satisfied post-graduate students than students in undergraduate level. Considering that the same learning framework is applied to those graduate level, postgraduate students may adopt the independent learning than undergraduate students.

The data indicates that student perceives there is differences in their experiences in online and offline classes. This provide opportunities to conduct further analysis to assess student perception towards those classes in Blended Programs in each higher education institutions.

Table 1. Data distribution towards student satisfactory

\begin{tabular}{|l||c|c|c|c|c|c|}
\hline \multicolumn{1}{|c|}{$\begin{array}{c}\text { Satisfaction } \\
\text { Level }\end{array}$} & \multicolumn{2}{c|}{ Online Class } & \multicolumn{2}{c|}{ Offline Class } & \multicolumn{2}{c|}{ Overall } \\
\cline { 2 - 7 } & \# Repondent & $\%$ & \# Repondent & $\%$ & \# Repondent & $\%$ \\
\hline Unsatisfied & 124 & $17 \%$ & 83 & $14 \%$ & 207 & $15 \%$ \\
\hline Neutral & 339 & $46 \%$ & 252 & $42 \%$ & 591 & $44 \%$ \\
\hline Satisfied & 280 & $38 \%$ & 269 & $45 \%$ & 549 & $41 \%$ \\
\hline Total & 743 & $100 \%$ & 604 & $100 \%$ & 1347 & $100 \%$ \\
\hline
\end{tabular}

Table 2 shows the data distribution of student satisfaction in undergraduate level in each student program from different higher education institutions. It is observed that students might be satisfied more in online classes than offline classes in a study program and more satisfied in offline classes in another study program. There is no superiority in student satisfaction among offline classes and online classes. In undergraduate level, students in four study programs are more satisfied in offline classes than online classes, while students in a study program are more satisfied in online class than offline class. The dissatisfaction student is also mixed among online and offline classes. Two study programs have higher student dissatisfaction in offline classes than offline classes, while students the other three study programs have student dissatisfaction in online classes that offline classes. This data indicates that online classes using e-learning method and traditional face-to-face method may deliver comparable student satisfaction. The elearning method used in the higher education institutions provide comparable learning experience to students. 
Table 2. Data descriptive for student satisfaction in online and offline classes - Undergraduate Study

\begin{tabular}{|c|c|c|c|c|c|c|c|c|c|}
\hline \multirow[b]{2}{*}{ Study Program } & \multirow[b]{2}{*}{ \# Respondent } & \multicolumn{4}{|c|}{ Online Class } & \multicolumn{4}{|c|}{ Offline Class } \\
\hline & & Unsatisfied & Neutral & Satisfied & Total & Unsatisfied & Neutral & Satisfied & Total \\
\hline \multirow{2}{*}{ S1 Akt STEl } & Student & 5 & 11 & 5 & 21 & 2 & 8 & 4 & 14 \\
\hline & $\%$ & $24 \%$ & $52 \%$ & $24 \%$ & $100 \%$ & $14 \%$ & $57 \%$ & $29 \%$ & $100 \%$ \\
\hline \multirow{2}{*}{ S1 Akt Usahid } & Student & 24 & 26 & 13 & 63 & 7 & 12 & 9 & 28 \\
\hline & $\%$ & $38 \%$ & $41 \%$ & $21 \%$ & $100 \%$ & $25 \%$ & $43 \%$ & $32 \%$ & $100 \%$ \\
\hline \multirow{2}{*}{ S1 Mgn ITHB } & Student & 1 & 31 & 44 & 76 & 2 & 29 & 41 & 72 \\
\hline & $\%$ & $1 \%$ & $41 \%$ & $58 \%$ & $100 \%$ & $3 \%$ & $40 \%$ & $57 \%$ & $100 \%$ \\
\hline \multirow{2}{*}{ S1 Mng STEI } & Student & 7 & 25 & 10 & 42 & 5 & 24 & 13 & 42 \\
\hline & $\%$ & $17 \%$ & $60 \%$ & $24 \%$ & $100 \%$ & $12 \%$ & $57 \%$ & $31 \%$ & $100 \%$ \\
\hline \multirow{2}{*}{ S1 Mng Usahid } & Student & 70 & 139 & 87 & 296 & 57 & 81 & 88 & 226 \\
\hline & $\%$ & $24 \%$ & $47 \%$ & $29 \%$ & $100 \%$ & $25 \%$ & $36 \%$ & $39 \%$ & $100 \%$ \\
\hline
\end{tabular}

Table 3 shows the data distribution of student satisfaction in postgraduate level in each student program from different higher education institutions. It is observed that students might be satisfied more in online classes than offline classes in a study program and more satisfied in offline classes in another study program. There is no superiority in student satisfaction among offline classes and online classes. Students in two study programs are more satisfied in offline classes than online classes, while students in a study program are more satisfied in online classes than offline classes. The dissatisfaction student is also mixed among online and offline classes. Two study programs have higher student dissatisfaction in offline classes than offline classes, while students the other three study programs have student dissatisfaction in online classes that offline classes. This data indicates that online classes using e-learning method and traditional face-to-face method may deliver comparable student satisfaction. The e-learning method used in the higher education institutions provide comparable learning experience to students.

Table 3. Data descriptive for student satisfaction in online and offline classes postgraduate Programs

\begin{tabular}{|c|c|c|c|c|c|c|c|c|c|}
\hline \multirow[b]{2}{*}{ Study Program } & \multirow[b]{2}{*}{ \# Respondent } & \multicolumn{4}{|c|}{ Online Class } & \multicolumn{4}{|c|}{ Offline Class } \\
\hline & & Unsatisfied & Neutral & Satisfied & Total & Unsatisfied & Neutral & Satisfied & Total \\
\hline \multirow{2}{*}{ S2 MM Ukrida } & Student & 2 & 43 & 59 & 104 & 1 & 38 & 47 & 86 \\
\hline & $\%$ & $2 \%$ & $41 \%$ & $57 \%$ & $100 \%$ & $1 \%$ & $44 \%$ & $55 \%$ & $100 \%$ \\
\hline \multirow{2}{*}{ S2 MM Usahid } & Student & 1 & 14 & 29 & 44 & 2 & 9 & 24 & 35 \\
\hline & $\%$ & $2 \%$ & $32 \%$ & $66 \%$ & $100 \%$ & $6 \%$ & $26 \%$ & $69 \%$ & $100 \%$ \\
\hline \multirow{2}{*}{ S2 Ilkom UMJ } & Student & 14 & 50 & 33 & 97 & 7 & 51 & 43 & 101 \\
\hline & $\%$ & $14 \%$ & $52 \%$ & $34 \%$ & $100 \%$ & $7 \%$ & $50 \%$ & $43 \%$ & $100 \%$ \\
\hline
\end{tabular}

Research data is analyzed further to find out factors that may contribute to student satisfaction. Table 4 shows the statistical model that consists of all factors related to student satisfaction in online classes in both undergraduate and postgraduate level. All coefficients are positively related student satisfaction that indicates the satisfaction increases if the research variables increase. Among the model variables, encouragement and exercise are the main determinants affect student satisfaction. Lecturer's encouragement to involve students' participation during live sessions is a 
significant driver to increase student satisfaction. Student also value the exercises given to students that require them to practice and workout.

Table 4. Statistical result of coefficient on all respondents in online classes

\begin{tabular}{|c|c|c|c|c|c|c|c|}
\hline Model & $\begin{array}{c}\text { Unstandard. } \\
\text { b }\end{array}$ & SE & $\begin{array}{c}\text { Standard. } \\
\text { b }\end{array}$ & $t$ & Sig. & $\begin{array}{c}\text { Collinearity } \\
\text { Tol }\end{array}$ & VIF \\
\hline Constant & 0,25 & 0,12 & 0,00 & 2,15 & 0,03 & 0,00 & 0,00 \\
\hline Encouragement & 0,18 & 0,05 & 0,21 & 3,52 & 0,00 & 0,27 & 3,69 \\
\hline Discussion & 0,03 & 0,06 & 0,04 & 0,59 & 0,56 & 0,21 & 4,83 \\
\hline Guidance & 0,01 & 0,06 & 0,01 & 0,11 & 0,91 & 0,21 & 4,81 \\
\hline Material_Understood & 0,03 & 0,05 & 0,04 & 0,64 & 0,52 & 0,22 & 4,59 \\
\hline Content & 0,06 & 0,05 & 0,07 & 1,11 & 0,27 & 0,26 & 3,86 \\
\hline Exercise & 0,18 & 0,05 & 0,23 & 3,81 & 0,00 & 0,27 & 3,73 \\
\hline
\end{tabular}

$\mathrm{N}=743, \mathrm{r}=0.05$

Table 5 shows the statistical model that consists of all factors related to student satisfaction in online classes in undergraduate level. All coefficients are positively related student satisfaction that indicates the satisfaction increases if the research variables increase. Among the model variables, encouragement and exercise are the main determinants affect student satisfaction. Lecturer's encouragement to involve students' participation during live sessions is a significant driver to increase student satisfaction. Student also value the exercises given to students that require them to practice and workout.

Table 5. Statistical result of coefficient in online class respondents in undergraduate level

\begin{tabular}{|c|c|c|c|c|c|c|c|}
\hline Model & $\begin{array}{c}\text { Unstandard. } \\
\text { b }\end{array}$ & SE & $\begin{array}{c}\text { Standard. } \\
\text { b }\end{array}$ & $\mathbf{t}$ & Sig. & $\begin{array}{c}\text { Collinearity } \\
\text { Tol }\end{array}$ & VIF \\
\hline Constant & 0,26 & 0,14 & 0,00 & 1,81 & 0,07 & 0,00 & 0,00 \\
\hline Encouragement & 0,14 & 0,06 & 0,17 & 2,26 & 0,02 & 0,26 & 3,80 \\
\hline Discussion & 0,03 & 0,06 & 0,04 & 0,54 & 0,59 & 0,22 & 4,46 \\
\hline Guidance & 0,01 & 0,07 & 0,01 & 0,15 & 0,88 & 0,22 & 4,52 \\
\hline Material_Understood & 0,05 & 0,06 & 0,07 & 0,86 & 0,39 & 0,23 & 4,27 \\
\hline Content & 0,06 & 0,06 & 0,07 & 0,92 & 0,36 & 0,26 & 3,80 \\
\hline Exercise & 0,17 & 0,06 & 0,22 & 2,95 & 0,00 & 0,27 & 3,73 \\
\hline
\end{tabular}

$\mathrm{N}=498, \mathrm{r}=0.05$

Table 6 shows the statistical model that consists of all factors related to student satisfaction in online classes in undergraduate level. All coefficients are positively related student satisfaction that indicates the satisfaction increases if the research variables increase. The encouragement and exercise consistently become the main determinants affect student satisfaction in undergraduate and postgraduate level. Lecturer's encouragement to involve students' participation during live sessions is a significant driver to increase student satisfaction. Student also value the exercises given to students that require them to practice and workout. 


\begin{tabular}{|c|c|c|c|c|c|c|c|}
\hline Table 6. Statistical & esult of coeffi & ent in & nline class & espond & $n t s$ in po & st-graduate & evel \\
\hline Model & $\begin{array}{c}\text { Unstandard. } \\
\text { b }\end{array}$ & SE & $\begin{array}{c}\text { Standard. } \\
\text { b }\end{array}$ & $t$ & Sig. & $\begin{array}{c}\text { Collinearity } \\
\text { Tol }\end{array}$ & VIF \\
\hline Constant & 0,47 & 0,21 & 0,00 & 2,26 & 0,02 & 0,00 & 0,00 \\
\hline Encouragement & 0,23 & 0,08 & 0,29 & 2,91 & 0,00 & 0,31 & 3,21 \\
\hline Discussion & 0,01 & 0,11 & 0,01 & 0,10 & 0,92 & 0,17 & 6,03 \\
\hline Guidance & 0,00 & 0,10 & 0,00 & 0,01 & 0,99 & 0,19 & 5,40 \\
\hline Material_Understood & $-0,06$ & 0,10 & $-0,08$ & $-0,59$ & 0,55 & 0,18 & 5,52 \\
\hline Content & 0,11 & 0,09 & 0,14 & 1,25 & 0,21 & 0,25 & 4,04 \\
\hline Exercise & 0,17 & 0,08 & 0,22 & 2,10 & 0,04 & 0,28 & 3,51 \\
\hline
\end{tabular}

$\mathrm{N}=245, \mathrm{r}=0.05$

Table 7 shows the statistical model that consists of all factors related to student satisfaction in offline classes in undergraduate and postgraduate level. Among the model variables, the main determinants affecting student satisfaction include discussion, feedback, lecturer competency, material understood and exercise.

Table 7. Statistical result of coefficient on all respondents in offline classes

\begin{tabular}{|l|c|c|c|c|c|c|c|}
\hline \multicolumn{1}{|c|}{ Model } & $\begin{array}{c}\text { Unstandard. } \\
\text { b }\end{array}$ & SE & $\begin{array}{c}\text { Standard. } \\
\text { b }\end{array}$ & t & Sig. & $\begin{array}{c}\text { Collinearity } \\
\text { Tol }\end{array}$ & VIF \\
\hline Constant & $-0,08$ & 0,12 & 0,00 & $-0,71$ & 0,48 & 0,00 & 0,00 \\
\hline Encouragement & 0,05 & 0,07 & 0,06 & 0,73 & 0,47 & 0,15 & 6,85 \\
\hline Discussion & 0,24 & 0,06 & 0,30 & 4,21 & 0,00 & 0,19 & 5,28 \\
\hline Feedback & 0,17 & 0,08 & 0,21 & 2,28 & 0,02 & 0,12 & 8,50 \\
\hline Learning_Objective & $-0,01$ & 0,08 & $-0,01$ & $-0,08$ & 0,93 & 0,11 & 8,90 \\
\hline Lecturer_Competency & 0,22 & 0,06 & 0,25 & 3,37 & 0,00 & 0,17 & 5,81 \\
\hline Guidance & $-0,02$ & 0,07 & $-0,02$ & $-0,23$ & 0,82 & 0,14 & 7,21 \\
\hline Assignment & 0,08 & 0,07 & 0,10 & 1,28 & 0,20 & 0,15 & 6,57 \\
\hline Material_Understood & $-0,25$ & 0,08 & $-0,30$ & $-3,12$ & 0,00 & 0,10 & 9,57 \\
\hline Execise & 0,08 & 0,08 & 0,10 & 1,09 & 0,27 & 0,12 & 8,37 \\
\hline
\end{tabular}

$\mathrm{N}=604, \mathrm{r}=0.05$

Table 8 shows the statistical model that consists of all factors related to student satisfaction in offline classes in undergraduate and postgraduate level. Among the model variables, the main determinants affecting student satisfaction include discussion, feedback, lecturer competency and material understood. 


\begin{tabular}{|c|c|c|c|c|c|c|c|}
\hline Table 8. Stat & stical result o & coeffici & nt in offline & classes & in underg & raduate level & \\
\hline Model & $\begin{array}{c}\text { Unstandard. } \\
\text { b }\end{array}$ & SE & $\begin{array}{c}\text { Standard. } \\
\text { b }\end{array}$ & $\mathbf{t}$ & Sig. & $\begin{array}{c}\text { Collinearity } \\
\text { Tol }\end{array}$ & VIF \\
\hline Constant & $-0,14$ & 0,14 & 0,00 & $-0,98$ & 0,33 & 0,00 & 0,00 \\
\hline Encouragement & 0,06 & 0,09 & 0,07 & 0,71 & 0,48 & 0,13 & 7,77 \\
\hline Discussion & 0,26 & 0,09 & 0,32 & 2,96 & 0,00 & 0,13 & 8,00 \\
\hline Feedback & 0,21 & 0,10 & 0,25 & 2,05 & 0,04 & 0,10 & 10,34 \\
\hline Learning_Objective & $-0,04$ & 0,11 & $-0,05$ & $-0,38$ & $\overline{0,71}$ & 0,09 & 11,42 \\
\hline Lecturer_Competency & 0,22 & 0,09 & 0,26 & 2,35 & 0,02 & 0,12 & 8,31 \\
\hline Guidance & 0,03 & 0,11 & 0,04 & 0,30 & 0,76 & 0,09 & 11,62 \\
\hline Assignment & 0,04 & 0,09 & 0,05 & 0,44 & 0,66 & 0,11 & 9,06 \\
\hline Material_Understood & $-0,34$ & 0,11 & $-0,41$ & $-3,14$ & 0,00 & 0,08 & 12,08 \\
\hline Execise & 0,15 & 0,10 & 0,18 & 1,48 & 0,14 & 0,10 & 10,35 \\
\hline
\end{tabular}

$\mathrm{N}=382, \mathrm{r}=0.05$

Table 9 shows the statistical model that consists of all factors related to student satisfaction in offline classes in undergraduate and postgraduate level. Among the model variables, the main determinants affecting student satisfaction include discussion, feedback, lecturer competency and material understood.

Table 9. Statistical result of coefficient on offline classes

respondents in postgraduate level

\begin{tabular}{|c|c|c|c|c|c|c|c|}
\hline Model & $\begin{array}{c}\text { Unstandard. } \\
\text { b }\end{array}$ & SE & $\begin{array}{c}\text { Standard. } \\
\text { b }\end{array}$ & $t$ & Sig. & $\begin{array}{c}\text { Collinearity } \\
\text { Tol }\end{array}$ & VIF \\
\hline Constant & 0,31 & 0,25 & 0,00 & 1,28 & 0,20 & 0,00 & 0,00 \\
\hline Encouragement & $-0,02$ & 0,12 & $-0,02$ & $-0,13$ & 0,90 & 0,19 & 5,18 \\
\hline Discussion & 0,27 & 0,08 & 0,35 & 3,58 & 0,00 & 0,34 & 2,95 \\
\hline Feedback & 0,06 & 0,13 & 0,07 & 0,47 & 0,64 & 0,16 & 6,29 \\
\hline Learning_Objective & $\overline{0,05}$ & 0,12 & 0,06 & 0,42 & 0,67 & $\overline{0,17}$ & $\overline{5,98}$ \\
\hline Lecturer_Competency & 0,17 & 0,09 & 0,20 & 1,86 & 0,06 & 0,28 & 3,53 \\
\hline Guidance & $-0,04$ & 0,09 & $-0,05$ & $-0,43$ & 0,67 & 0,27 & 3,70 \\
\hline Assignment & 0,12 & 0,09 & 0,15 & 1,30 & 0,19 & 0,24 & 4,13 \\
\hline Material_Understood & $-0,01$ & 0,12 & $-0,01$ & $-0,09$ & 0,93 & 0,14 & 7,25 \\
\hline Execise & $-0,09$ & 0,12 & $-0,11$ & $\begin{array}{l}-0,78 \\
\end{array}$ & 0,44 & 0,17 & 6,02 \\
\hline
\end{tabular}

$\mathrm{N}=222, \mathrm{r}=0.05$

Table 10 show the On Way Anova test to examine student satisfaction in online classes and offline classes for all respondents. The standard deviations (0.699 and $0.707)$ and standard errors (0.028 and 0.026$)$ of both data groups indicate the likelihood that the variances of each means are not from each other. The statistical result shows there is no significant variation among satisfaction level in online classes and offline classes across study programs and higher education institutions. 
Students perceive that the learning methods through online and offline class do not have differences in achieving their expectation to accomplish learning objective.

Table 10. One Way Anova Test on student satisfaction in online classes versus offline classes

\begin{tabular}{|l|c|c|c|c|c|c|c|c|}
\hline \multicolumn{1}{|c|}{ Score } & $\mathrm{N}$ & Mean & SD & SE & $95 \%$ CI LB & $95 \%$ CI UB & Levene & Sig \\
\hline Offline & 604 & 2,308 & 0,699 & 0,028 & 2,252 & 2,364 & & \multirow{2}{*}{0,14} \\
\cline { 1 - 7 } Online & 743 & 2,210 & 0,707 & 0,026 & 2,159 & 2,261 & \multirow{2}{*}{0,14} \\
\cline { 1 - 7 } Total & 1347 & 2,254 & 0,705 & 0,019 & 2,216 & 2,292 & & \\
\hline
\end{tabular}

The variation of means of data groups is presented in the chart 1 that describes the difference within scale of 3 . It shows that the difference between means of student satisfaction in online data group and offline data group is 0.01 which is not statistically significant.

Chart 1. Variance of means of student satisfaction data groups

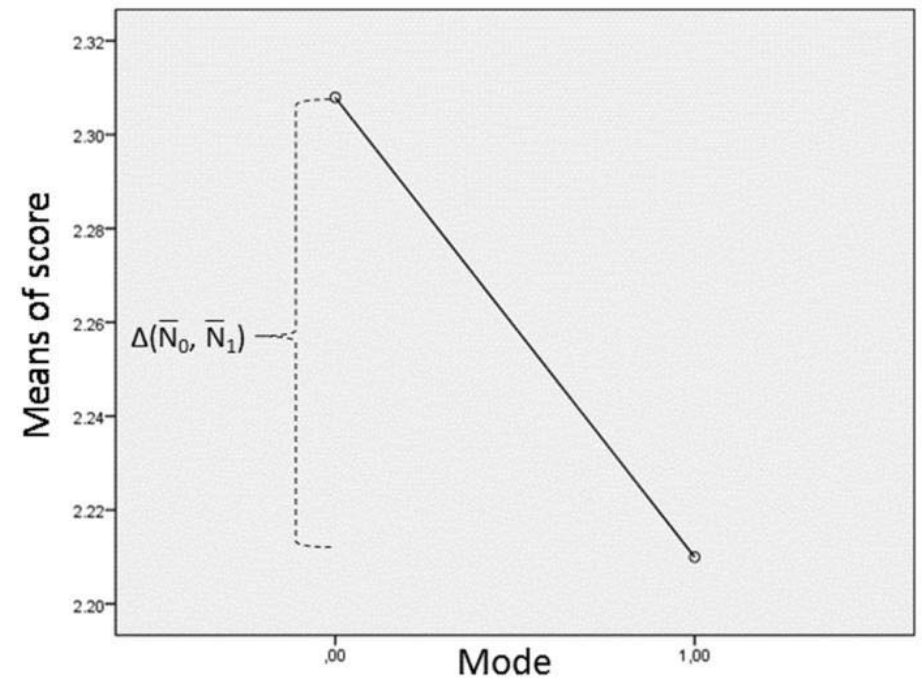

\section{Discussions}

Student satisfaction data is examined in different study programs across different higher education institutions in Blended Programs. In particular, the student satisfaction data is compared to assess how students perceive their experiences in learning in online and offline classes. 85\% students perceived that they are satisfied and neutral in their experiences studying in Blended Programs. It is observed from data descriptive that there is variation in percentages of students who perceived more satisfied and neutral in offline classes (84\%) than online classes (87\%). However, the result of statistical test indicates that the difference among data means of those groups is not statistically significant. Students perceive that their learning experiences in studying in online classes and offline classes is comparable to meet their learning expectation. Students' preference towards learning experiences in online and offline classes are mixed. There are students in undergraduate and postgraduate level perceiving that their satisfaction is higher in online 
classes than offline classes. Contrarily, some students in different study programs across graduate level perceive their satisfaction is higher in offline classes than online classes.

Encouragement and exercise are the determinants contributing to student satisfaction in online classes. The effect of these factors are consistent across study programs and graduate levels. These two factors have the highest coefficients within the statistical results, 0,18 and 0,18 in all online classes, 0,14 and 0,17 in undergraduate online classes and 0,23 and 0,17 in postgraduate online classes. Students value the lecturer's encouragement to bring students participating in class discussion during live sessions. It is the important phase within e-learning process that create learning interaction by encouraging students to give their opinions or suggestions to the learning materials. Students also value the exercises provided for them to practice and workout learning materials. In the absence of physical meeting with lecturer and peers, students need to have quizzes, individual assignments and group assignment to help them understand more about the materials. E-learning system that is developed to facilitate encouragement and exercise for students is able to deliver a comparable learning method to face-to-face method.

The determinants that affect student satisfaction are different in online and offline classes. Discussion, feedback, lecturer competency and understood materials are the determinants that affect student satisfaction when testing was conducted using all offline classes data. Such determinants are predictable as the nature of offline class is face to face interaction between lecturer and students and students to their peers. The competency of lecturer, ability to teach and prepare teaching material are important to help students achieve the learning objective. However, discussion is the only factor that is consistent as the determinant to affect student satisfaction in undergraduate and postgraduate level. The coefficients of discussion factor $(0.26$ for undergraduate data testing and 0.27 for postgraduate data testing) are the highest among other coefficients of statistical models. Students in undergraduate and postgraduate level perceive that the quality of class discussion in face to face method contribute significantly to their satisfaction. The feedback, lecturer competency and understood materials only significantly affect student satisfaction in undergraduate level. The variation of findings from data analysis indicates that student satisfaction in offline classes are different across graduate level.

\section{Conclusion}

The research on student satisfaction in e-learning programs, particularly in blended programs, has gained insights towards students' learning experience in virtual classes and face-to-face classes. Student satisfaction has been identified in online classes across different program studies, different graduate level and different higher education institutions. The e-learning system is able to achieve equivalent learning objective compared to face-to-face classes in which students from some study programs are more satisfied in online classes than in offline classes. Although some 
differences were found in some study programs, the variation among student satisfaction in online classes and offline classes is statistically different. This finding provides evidence that e-learning can

be an alternative learning method to replace face-to-face classes with equivalent student satisfaction.

The data analysis found that determinants affecting student satisfaction in online classes are different to determinants of student satisfaction in offline classes. Student satisfaction in online classes is driven by encouragement and exercise factor. The effect of those factors are applicable to the nature of online class where lecturer and students and students with their peers are interacted virtually. Students in online classes are satisfied when lecturer encourage them to discuss and express their opinions after independently study their digital materials. The students in online classes also expect to have exercises, quizzes and assignments for practicing what they learnt. The determinants of student satisfaction in offline classes are discussion, feedback, lecturer competency and understood materials. These factors represent lecturer and student interaction in offline classes where learning is conducted through face-to-face mode. However, discussion factor is robust across graduate level that become consistent determinant in graduate and postgraduate level.

\section{References}

Adnan, Al-Rafai, Mohamed, Al-Fahad, Tarek, Arafa, Mun, Son and Hosny, Hamdy (2016), Measuring Student Satisfaction with Performance Enhancement Activities: Evidence from Business Education, International Journal of Information and Education Technology, 6, 10, p. 741-753.

Ammigan, Ravichandran and Jones, Elspeth (2018), Improving the Student Experience: Learning From a Comparative Study of International Student Satisfaction, Journal of Studies in International Education, 22, 4, p. 283-301.

Burgess, Adrian, Senior, Carl and Moores, Elisabeth (2018), A 10-year case study on the changing determinants of university student satisfaction in the UK, Feb 23. Assessment of Students' Satisfaction: A Case Study of Dire Dawa University, Ethiopia

Daniel, Dawit; Liben, Getachew; Adugna, Ashenafi (2017), Assessment of Students' Satisfaction: A Case Study of Dire Dawa University, Ethiopia, 8, 4, p. 111-120.

Farahmandian,Sepideh, Minavand, Hadi and Afshardost, Mona (2013), Perceived service quality and student satisfaction in higher education, IOSR Journal of Business and Management, 12, 4, p. 65-74.

Goh, Chin Fei, Leong, Choi Meng, Kasmin, Kalsum, Hii, Puong Koh and Tan, Owee Kowang (2017), Students' experiences, learning outcomes and satisfaction in e-learning, Journal of e-Learning and Knowledge Society, 13, 2, p. 117-128. 
Gortan, Alenka and Jereb, Eva (2007), The Dropout Rate from E-Learning Courses and the Satisfaction of Students with E-Learning, Organizacija, 40, 6, p. 248257.

Hanssen, Thor-Erik Sandberg and Solvoll, Gisle (2015) "The importance of university facilities for student satisfaction at a Norwegian University", Facilities, 33, 13/14, p.744-759.

Lukić, Vesna Rodić and Lukić, Nemanja (2018), Assessment of student satisfaction model: evidence of Western Balkans, Journal Total Quality Management \& Business Excellence, 20 June.

Strong, Robert, Irby, Travis L., Wynn, J. Thomas and McClure, Megan M. (2012), Investigating Students' Satisfaction with eLearning Courses: The Effect of Learning Environment and Social Presence, Journal of Agricultural Education, 53,3, p 98-110.

Weerasinghe, IM Salinda and Fernando, R. Lalitha, S. (2017), Students' Satisfaction in Higher Education, American Journal of Educational Research, 5, 5, p. 533539. 